\title{
The Youth Generation Development Patterns in Efforts to Improve Relationship Between Religious People in the Context of Resistance
}

\author{
${ }^{1}$ Grystin Djein Sumilat* \\ Department of Geography Education \\ Social Science Faculty \\ Universitas Negeri Manado \\ Manado, Indonesia \\ grystinsumilat@unima.ac.id
}

\author{
${ }^{2}$ Syulke Tombeg \\ Department of History Education \\ Faculty of Social Sciences, Manado \\ Universitas Negeri Manado \\ Tondano, Indonesia \\ syulketombe@unima.ac.id
}

\begin{abstract}
This research problem is related to the pattern of coaching the young generation to improve relations between diverse people in the context of national resilience. The purpose of this study is to determine the effectiveness of the pattern of implementation of the younger generation by related agencies, as well as to determine what factors are causing the potential for harmony and the potential for non-harmony in religious life. The method used is the descriptive-qualitative method, and data collection techniques are interviews and questionnaires. The results showed that the implementation of coaching the younger generation by relevant agencies was quite effective. This has proven to be a change in attitude and mentality of the younger generation so that fighting between different youths can be minimized. Religious organizations play an essential role in shaping the attitudes and mindset of young people by organizing together in the form of spiritual activities, especially before and after the celebration of religious holidays. To prevent potential conflicts between religious communities and especially the younger generation, religious leaders play an active role in carrying out dialogue and cooperation to discuss social issues that reek of SARA. The potential for community harmony is relatively good, and the relationship between religious communities is quite strong. Peace can be maintained so that people can live side by side with one another, respecting each other and respecting the value of kinship with the spirit of Torang Samua Basudara. The potential for disharmony exists in the community in this area, namely sermons that offend adherents of other religions, issues of illegal leaflets. Therefore, it can be concluded that effective coaching of young generation in the sense of fostering the mentality and morality of the younger generation well, by themselves they can avoid descriptive actions that lead to social conflict. Likewise, harmonious relations between religious communities will ensure the creation of resilient and resilient national resilience conditions for the realization of the quality of society to improve living standards and well-being as well as the ability to ward off all threats, challenges, obstacles, disturbances (ATHG), both coming from inside and outside country.
\end{abstract}

Keywords: The young generation, Harmony, Non-harmony, National Resilience

\section{INTRODUCTION}

Various acts of violence that occurred in the form of mass amok (mostly young people) have occurred in recent years with an increasingly worrisome identity. The mass violence was characterized by beatings, destroying persecution, and even murder. This kind of abuse certainly tarnishes the spirit of national unity and unity that we have upheld so far, so, naturally, various parties try to make statements and analyses to find explanations and solutions to these problems [1].

According to Thajeb, coaching the young generation is an integral part of the education process or fostering the nation. Since the level of education of the Indonesian people is still low, efforts and activities that deliberately, regularly, and plan to be carried out to improve the level of education become a necessity. For this purpose, young people cannot act as objects, but also young people must be subject. This means that efforts to increase the level of education of this nation become the pattern of responsibility of the educated young generation [2].

In addition to fostering the younger generation, the harmony of religious life is an essential and urgent factor in the framework of national security, especially for diverse Indonesian nations: ethnicity, ethnicity, religion, and race (SARA). Religious people everywhere will always face conflict and disharmony and will always look for a mode of harmony so that their lives usually run. So, peace still has potential in the community itself [3].

Physical conflicts between residents (involving many young people) that take place in many regions of the country provide a clear signal that the social sensitivity and resilience of the community at the local level can no longer be maintained by relying on current social mechanisms. The use of religious and tribal symbols in many cases of conflict implies that the new social mechanism that was built during the original order. It had ignored primordial aspects that were commonly influential in agrarian communities, namely religious and cultural ties of the tribe [3]. 
To create an atmosphere of harmony and peace in the sense of mutual respect and respect among adherents of existing religions is the responsibility of all components of the nation's strength. If the harmonious atmosphere is realized it will have an impact or positive implications on the power of national resilience (which is now recognized to be somewhat disturbed) because of the social turmoil that is sweeping the Indonesian nation.

Likewise, with the way of life of the people in Manado City, especially the younger generation, there is a tendency to live a relaxed and spree-like lifestyle. One of the factors causing this tendency is an increase in the number of workers, both high school and college graduates, while the available employment is minimal. No wonder that many young people have to live in groups while drinking to get drunk, making noise both on the streets, alleys, stalls and in other crowded places. Even to the point of fighting between gangs between groups and between villages, involving young people who happened to be of different ethnicity or religion.

The diversity of people in the city of Manado that has a different value system will at least produce two alternatives, both positive and negative. This is positive if the meeting and interaction can create an atmosphere of harmonious social relations in society. This condition can be achieved if each religion adheres to each other, respects, and recognizes the existence of other ethnic groups and adherents, and can minimize things that can cause conflicts or conflicts and open feelings, tolerance so that differences in the cultural value system can be suppressed, reduced and enhanced activities to achieve common interests. The negative things that arise when there is coercion of values or norms. Adopted by those who feel the majority to the minority, and vice versa. This can cause relationships between religious believers to become tense and quickly lead to social conflict.

Specifically, Kleak Urban Village is one of nine Urban Village in Malalayang Sub-District, Manado City. Even though the location of Kleak Uban Village is not in the middle of the city, but the diversity of the community is evident. Because Kleak Urban Village is close to the UNSRAT campus, Ratumbuysang hospital, Kelabat Stadium and other public offices. Kleak Urban Village is domiciled by many young men and women who come from various regions with different ethnic backgrounds, religions, and social status. They lived and boarded in the Kleak village because the study also worked, including residents. The diversity of regional backgrounds, ethnicities, religions and social status on the one hand as the strength and wealth of the community but on the other hand, such differences can be a significant challenge as the integrity of a community or region. Friction between young people from the Irian region who live in their homestead areas often occurs.

This writer formulates several problems: a) What is the pattern of coaching young generation to improve relations between religious communities in Kleak Urban Village?; b) What is the relationship between the religious generation of the younger generation in Kleak Urban Village?; c) What are the implications of harmony among religions on the condition of national resilience in terms of the socio-cultural aspects of the Kleak Urban Village?

\section{RESEARCH METHOD}

The analytical method used in this research is a descriptive qualitative method. A descriptive approach is an approach that intends to understand phenomena about what is experienced by research subjects holistically and in a descriptive way in the form of words and language, not using statistics [4].

In this study, researchers used a qualitative descriptive approach, because the issues to be discussed in this study are not related to numbers but rather describe, describe and illustrate the pattern of coaching young generation to improve relations between religious communities in the context of national resilience.

The data sources in this study are the local government, the sub-district head of religious leaders, and BKSAUA leaders. The characters in question are people who are considered to have knowledge and experience in the field of formation of generation, youth and religious grounds (Protestant Christianity, Catholicism, Hinduism and Buddhism Islam) in the Kleak Urban Village of Manado City. The data source above consists of key information (key informants), namely leaders / religious leaders consisting of 15 people, while informants can, namely respondents who provide answers in the form of information through questionnaires distributed in Kleak Urban Village.

This respondent consists of leaders namely: from Protestant Christians (Priest, elders, and shamas or deacons); from Catholicism (Priest, and head of the community); from the religion of Islam (Kyai). Retrieval and determination of the number of respondents are carried out prepositionally for each subdistrict according to the number of residents and followers of existing religions. Data collected in this study are qualitative data in the form of primary data and secondary data. By this type of research (qualitative research), the data collected was analyzed using descriptive-qualitative analysis techniques.

\section{RESULT AND DISCUSSION}

\section{Youth Development Patterns}

The creation of religious harmony is the implementation of the GMIM youth session in a calm atmosphere because it is characterized by friendship, intimacy, and a high enough spirit of brotherhood. The program of the City of BKSAUA of Manado cannot be separated from the active role of the younger generation in supporting and supporting efforts to increase cooperation between religious communities in the City of Manado to always create a harmonious and peaceful atmosphere and a high spirit of brotherhood, especially in regard to responding to social upheavals that occur in 
various regions in Indonesia, and the efforts of provocateurs to pitting religious believers through dark leaflets that had been circulating in the city of Manado.

To anticipate things that are not wanted by all the people of Manado, especially the Kleak Village community, the young generation in each sub-district in the city of Manado carries out various activities in the form of interfaith youth dialogue. In Molas District, for example, the young generation formed a Committee together with Eid al-Adha $1419 \mathrm{H}$, which involved church youth and mosque youth throughout Molas District, which was held almost every year. This activity was carried out by the church's young generation and the mosque's young generation with enthusiasm: Torang Samua Basudara, which became the slogan and philosophy of life of the people of Manado, and North Sulawesi in general [5], [6].

Religious people and young people, in particular, are expected to participate actively in efforts to strengthen security stability in the regions and national resilience as well as in efforts to carry out sustainable regional development-a sense of kinship in the community that animates and colours a culture of harmony and peace. With a touch of relationship, every religious adherent has an attitude of prioritizing shared prosperity rather than his pleasure and prefers integrating opinions with deliberations and consensus rather than pitting views based on the right approach and wanting to win himself. The sense of kinship fosters enthusiasm, an atmosphere of harmony and the integrity of the attitude of solidarity between citizens.

Coaching shows the activities of maintaining and perfecting what already exists [7], or in other words, coaching is an effort, action and activity carried out efficiently and successfully to obtain better results [8].

So coaching is basically an educational effort both formal and non-formal which is carried out consciously, planned, directed, organized and responsibly in order to introduce, grow, guide and develop the foundations of a balanced, intact and harmonious personality, knowledge and skills in accordance with talents, desires and abilities as provisions, henceforth on their own initiative add to enhance themselves, each other and their environment towards the achievement of optimal dignity, quality, and ability of students and independent individuals [7].

\section{Potential for Religious Harmony and Non-harmony}

The form of cooperation between religious communities in the city of Manado that is often done every year is to visit each other on religious holidays such as Christmas, New Year, Eid al-Fitr, Vesak, and Nyepi. In Manado, social interactions take place both among various ethnic, ethnic, indigenous and nonindigenous groups, as well as one religion with another religion.

The potential for religious harmony can be strengthened by several indicators of harmony obtained through interviews and questionnaires distributed.
Respondents 'answers to each sign are processed quantitatively in a tabular form and interpretations are made according to the respondents' reasons.

During this time, the relationship between religious communities in the Kleak urban village Manado is quite good. But that does not mean there is no potential for conflict that leads to division; as an example of the relationship between Christianity and Islam that can be put forward, where a portion of the two adherents of this religion raises issues, is suspicious of each other and accuses each other of efforts to Christianize and Islamize.

Thus it becomes the obligation of religious people, especially religious leaders and leaders to be able to maintain and foster cooperation in all fields so that they are always fostered with tri harmony, namely the internal harmony of religious communities; harmony between religions, and religious harmony with the government.

Both of these problems have positive and negative implications on the resilience of local communities as well as the stability and national resilience of Indonesia. With a positive assumption, namely that active and successful fostering of the younger generation, in the sense of fostering the mentality and morality of the younger generation well, naturally they consciously avoid themselves from destructive actions and lead to divisions in society. Such is the case with healthy and robust socio-cultural resilience and harmonious relations between religious communities, which will guarantee robust and dynamic national stability. In other words, it will always create conditions of resilient and resilient national resilience, in various aspects of life, namely: political, economic, socio-cultural and security and defence.

The negative thing is if there are youth fights of different religions and ethnicities always happening in Manado, it will have implications for the relationship between religious communities and the conditions of national resilience in general. The SARA issue that had occurred in Manado on March 14, 1970, indicated that a pluralistic society was vulnerable and social turmoil that smelled of SARA and could disrupt relations between religious communities, the problem could be overcome and resolved amicably by the local government, religious leaders together with BKSAUA Manado especially in Kleak urban village, so this problem is not sustainable (sources were taken from informants interviewed and from the community).

The potential for non-harmony in interfaith relations, in general, is something that always arises in the life of a pluralistic society, which is currently in poor condition. The SARA issues that have arisen lately are the potential for non-harmony that can endanger the unity and integrity of the community, not disrupt the stability and conditions of national security. The issue of interfaith is indeed very quickly aroused religious sentiments for its adherents, which can lead to conflict 
and open performance in the form of mass unrest as happened in several other regions.

Socially and culturally, the condition of a plural society is very potential for social conflict. Conflicts can occur due to differences in livelihoods, rich-poor, race, ancestry, language, culture and religion. Differences in faith and belief systems are susceptible and can lead to tendencies that are oriented to the interests of their groups, while other groups tend to be exclusive.

Public awareness of cultural values needs to be continuously developed and developed continuously from generation to generation, so as not to trigger social conflicts between different ethnic religions, or fellow religions but with different ethnicities. To anticipate and overcome social conflicts in the life of the community in the future, then one of the fields that gets the main attention to be given a role and to improve the quality of its services in the field of education and health. Improvements in the field of education and health are intended: to build the order of a modern, developed, Christian, systematic and rational society; and for the realization of social integration that can unite all the power components in a plural society; eliminate feelings of suspicion towards other ethnic and religious adherents.

Socio-cultural resilience is a condition of community life that has tenacity and resilience and contains the ability to develop and enhance harmony, especially in dealing with and overcoming various social problems, especially those relating to interfaith relations, both coming from the outside or from within, which are directly or indirectly can endanger the integrity of the community that has been living in harmony, safety, and peace.

In the 21 st century, a new name is needed for relationships between religious communities, so far the name used for harmony and tolerance. Harmony or tolerance, according to reference [9], has led to apologetic nature, each religion wants to show that he is the most harmonious and tolerant. Moreover, carried out textually (written teachings) and contextual (history, sociology, anthropology), which has added new tension. Muslims will state that the first word that is spoken by a Muslim is assalamualaikum. Therefore Islam is a religion of peace. Christian-Protestant and Catholic claim that Christianity is a religion of love or friendship. Hindus will state that their faith emphasizes the Dharma. Buddhists claim that their religion intends to release people from suffering [10].

\section{CONCLUSION}

1. The development of the younger generation by the government of the City of Manado, especially in Kleak Urban Village and related institutions is quite good and useful. It is recognized that so far, there have not been found social conflicts committed by the younger generation so that that community harmony can be improved, fostered, and well maintained.
2. The potential for disharmony between religious communities can occur, especially between Muslims and Christians. To anticipate things that are not desirable, the two adherents of this religion should be more active in being able to live in continuous collaboration towards the creation of a peaceful human society. Followers of religion recognize differences and similarities as humans who have a shared commitment in efforts to improve human dignity, regardless of ethnic/ethnic and religious differences.

\section{ACKNOWLEDGMENT}

Thank you to the Unima FIS Leaders who approved the plan for conducting this research, and to the Unima leadership who had provided research funding so that this article could be completed.

\section{REFERENCES}

[1] H. Nugroho, 'Agama, Kemajemukan dan Ketahanan Nasional: Sebuah Upaya Menolak Determinan Kerusuhan Sosial', Yogyakarta, 1997.

[2] H. Prajitno, Generasi Muda dan Ketahanan Nasional. Yogyakarta: Dewan Mahasiswa Universitas Gadjah Mada, 1975.

[3] Tim Puslitbang Kehidupan Beragama, Program Pendayagunaan Kerukunan Hidup Umat Beragama Bagi Peningkatan Ketahanan Masyarakat Lokal. Jakarta: Tim Puslitbang Kehidupan Beragama, 1999.

[4] L. J. Moleong, Metodologi Penelitian Kualitatif. Bandung: Remaja Rosdakarya, 2011.

[5] A. L. Lonto, Peran Elite Agama Dalam Membina Kerukunan Hidup Antarumat Beragama di Kota Manado/The Role of Religious Elite In Building Religious Interfaith Living in Manado City. Malang: Wineka Media, 2003.

[6] T. Pangalila, J. Mantiri, and J. Biringan, 'Nilai Moral yang Terkandung dalam Semboyan Torang Samua Basudara Sebagai Sumber Toleransi', J. Moral Kemasyarakatan, vol. 3, no. 2, pp. 71-77, 2019.

[7] B. Simanjuntak and I. L. Pasaribu, Membina dan Mengembangkan Generasi Muda. Bandung: Tarsito, 1980.

[8] W. J. S. Poerwadarminta, 'Kamus besar bahasa Indonesia', Jakarta: Balai Pustaka, 2002. 
[9] Kuntowijoyo, Identitas politik umat Islam. Mizan, 1997.

[10] C. Lay, 'Kekerasan Atas Nama Agama: Perspektif Politik', J. Ilmu Sos. dan Ilmu Polit., vol. 13, no. 1, pp. 1-19, 2009. 